\title{
Editorial
}

\section{Health-Related Quality of Life in Chronic Hepatitis C}

\author{
Helder Cardoso Marco Silva \\ Gastroenterology Department, Hospitalar Center of São João, Faculty of Medicine of the University of Porto, \\ Porto, Portugal
}

\section{Keywords}

Health-related quality of life - Chronic hepatitis C .

Antivirals $\cdot$ Patient-reported outcome measures

\section{Qualidade de Vida Relacionada com a Saúde na Hepatite C Crónica}

\section{Palavras Chave}

Qualidade de vida relacionada com a saúde · Hepatite C crónica · Antivíricos · Medições de resultados informados pelos doentes

Hepatitis $\mathrm{C}$ virus (HCV) infection is one of the main causes of liver disease and has a great impact on patient outcomes. The estimate of chronically infected persons is about 160 million worldwide, but most of them are unaware of the disease. The clinical impact of $\mathrm{HCV}$ infection is highly variable, from minimal changes to cirrhosis and hepatocellular carcinoma, with or without extrahepatic manifestations. Nevertheless, the outcome of HCV infection is not restricted to the clinical endpoints, as it can affect multiple health and psychosocial dimensions.

\section{KARGER}

E-Mail karger@karger.com www.karger.com/pjg
(C) 2017 Sociedade Portuguesa de Gastrenterologia Published by S. Karger AG, Basel

Karcer

Open access

This article is licensed under the Creative Commons AttributionNonCommercial-NoDerivatives 4.0 International License (CC BYNC-ND) (http://www.karger.com/Services/OpenAccessLicense) Usage and distribution for commercial purposes as well as any distribution of modified material requires written permission.
In recent years, $\mathrm{HCV}$ infection has become increasingly noticeable for different reasons. On the one hand, the development of highly effective antiviral therapy has enabled the actual treatment and cure of most diagnosed patients, but on the other hand, the burden from the most severe complications, such as hepatocellular carcinoma, keeps increasing $[1,2]$.

A comprehensive assessment of overall outcomes would include, besides clinical hepatic and extrahepatic manifestations, patient-reported outcomes (PRO) and economic consequences. A PRO is any report of the status of a patient's health condition that comes directly from the patient, without interpretation of the patient's response by a clinician or anyone else. It reflects patient experience using surrogate markers such as health-related quality of life (HRQoL), functional status, perceived stigma, and work productivity $[3,4]$. In this context, the study by Rei et al. [5] addresses an important topic and contributes to improve the scarce available Portuguese data. The main self-administered instruments used were the SF-12 (generic) and CLDQ (disease-specific) HRQoL questionnaires.

The first studies on the effects of $\mathrm{HCV}$ infection on patients' quality of life, using the short form SF-36 Health Survey, revealed that patients were polysymptomatic and

Dr. Helder Cardoso

Gastroenterology Department, Hospitalar Center of São João

Alameda Prof. Hernâni Monteiro

PT-4200-319 Porto (Portugal)

E-Mailhcmail@sapo.pt 
had diminished quality of life with significant reductions in all domains. The reduction in quality of life could not be attributed to the degree of liver inflammation or to the mode of acquisition of the infection. Hence, the authors conclude that chronic HCV infection gives rise to physical symptoms that reduce the quality of life of infected patients [6]. Also, studies with matched controls demonstrated that work productivity is significantly impaired [7]. Regarding cognitive performance, a meta-analysis of studies in HIV-infected patients demonstrated a higher level of cognitive impairment associated with $\mathrm{HCV}$ infection [8].

One of the most frequent extrahepatic manifestations is depression. A review of neuropsychiatric symptoms commonly associated with HCV infection showed that major depression was related to illness perception, functional disability, impaired quality of life, fatigue severity, and the presence of psychiatric comorbidity [9]. Likewise, in the study of Rei et al. [5], there was a high prevalence of mood disorders (namely depression) with a negative impact on HRQoL, and the authors therefore recommend screening and suitable psychosocial interventions in a multidisciplinary setting.

Regarding the impact of antiviral therapy on PRO, there were several concerns regarding interferon-based regimens, which negatively affected quality of life during treatment $[4,10,11]$. Recent studies with antiviral regimens without interferon or ribavirin demonstrated an improvement of quality of life during treatment coinciding with viral suppression within the first month of therapy [12]. Also, Rei et al. [5] reported that oral antiviral treatment could be correlated with HRQoL increases in some domains, which provides growing evidence for the multiple benefits of appropriate HCV treatment.

The achievement of a sustained virological response is associated with an improvement of clinical outcomes, namely a reduction of all-cause mortality [13]. The impact on PRO following successful HCV therapy is also significant; several studies with paired HRQoL assessments demonstrated an overall improvement of all domains of SF-36. Viral eradication leads to HRQoL improvement, regardless of fibrosis stage. HCV patients with early fibrosis experience similar improvement of PRO as those with advanced fibrosis $[12,14,15]$. Curiously, the HRQoL improvement was progressive over time after the end of treatment, with scores after 24 weeks greater than at 12 weeks [15]. It might be interesting to study what will be the time frame for an extensive recovery of HRQoL after sustained virological response, in relation to healthy controls. Another issue that would benefit from research is the extent of recovery of other PRO, such as perceived stigma and work productivity.

In this era of widespread HCV antiviral therapy, it is important to recognize the comprehensive burden of this disease as well as the value of achieving HCV cure, which translates into benefits at different levels for the patient and society.

\section{Disclosure Statement}

The authors have no conflicts of interest to declare.
1 European Association for the Study of the Liver: EASL recommendations on treatment of hepatitis C 2016. J Hepatol 2017;66:153194.

2 Cardoso H, Vale AM, Rodrigues S, Gonçalves R, Albuquerque A, Pereira P, Lopes S, Silva M, Andrade P, Morais R, Coelho R, Macedo G: High incidence of hepatocellular carcinoma following successful interferon-free antiviral therapy for hepatitis $\mathrm{C}$ associated cirrhosis. J Hepatol 2016;65:1070-1071.

3 Younossi Z, Kallman J, Kincaid J: The effects of HCV infection and management on healthrelated quality of life. Hepatology 2007;45: 806-816.
4 Marinho RT, Barreira DP: Hepatitis C, stigma and cure. World J Gastroenterol 2013;19: 6703-6709.

5 Rei A, Rocha M, Pedroto I: Health-related quality of life in Portuguese patients with chronic hepatitis C. GE Port J Gastroenterol DOI: $10.1159 / 000450875$.

6 Foster GR, Goldin RD, Thomas HC: Chronic hepatitis $\mathrm{C}$ virus infection causes a significant reduction in quality of life in the absence of cirrhosis. Hepatology 1998;27:209-212.

7 Vietri J, Prajapati G, El Khoury AC: The burden of hepatitis $\mathrm{C}$ in Europe from the patients' perspective: a survey in 5 countries. BMC Gastroenterol 2013;13:16.
8 Fialho R, Pereira M, Bucur M, Fisher M, Whale R, Rusted J: Cognitive impairment in HIV and HCV co-infected patients: a systematic review and meta-analysis. AIDS Care 2016;28:1481-1494.

9 Cruz Neves A, Dickens C, Xavier M: Comorbidity between hepatitis $\mathrm{C}$ and depression. Epidemiological and etiopathogenic aspects. Acta Med Port 2006;19:21-28.

10 Marcellin P, Chousterman M, Fontanges T, Ouzan D, Rotily M, Varastet M, Lang JP, Melin P, Cacoub P; CheObs Study Group: Adherence to treatment and quality of life during hepatitis $\mathrm{C}$ therapy: a prospective, real-life, observational study. Liver Int 2011;31:516524. 
11 Younossi ZM, Stepanova M, Nader F, Jacobson IM, Gane E, Nelson D, Lawitz E, Hunt SL: Patient-reported outcomes in chronic hepatitis $\mathrm{C}$ patients with cirrhosis treated with sofosbuvir-containing regimens. Hepatology 2014;59:2161-2169.

12 Younossi ZM, Stepanova M, Marcellin P, Afdhal N, Kowdley KV, Zeuzem S, Hunt SL: Treatment with ledipasvir and sofosbuvir improves patient-reported outcomes: results from the ION-1, -2 , and -3 clinical trials. Hepatology 2015;61:1798-1808.
13 Innes HA, McDonald SA, Dillon JF, Allen S, Hayes PC, Goldberg D, Mills PR, Barclay ST, Wilks D, Valerio H, Fox R, Bhattacharyya D, Kennedy N, Morris J, Fraser A, Stanley AJ, Bramley P, Hutchinson SJ: Toward a more complete understanding of the association between a hepatitis $C$ sustained viral response and cause-specific outcomes. Hepatology 2015;62:355-364.

14 Bonkovsky HL, Snow KK, Malet PF, BackMadruga C, Fontana RJ, Sterling RK, Kulig CC, Di Bisceglie AM, Morgan TR, Dienstag JL, Ghany MG, Gretch DR; HALT-C Trial Group: Health-related quality of life in patients with chronic hepatitis $\mathrm{C}$ and advanced fibrosis. J Hepatol 2007;46:420-431.
15 Younossi ZM, Stepanova M, Sulkowski M, Foster GR, Reau N, Mangia A, Patel K, Bräu N, Roberts SK, Afdhal N, Nader F, Henry L, Hunt S: Ribavirin-free regimen with sofosbuvir and velpatasvir is associated with high efficacy and improvement of patient-reported outcomes in patients with genotypes 2 and 3 chronic hepatitis C: results from ASTRAL-2 and -3 clinical trials. Clin Infect Dis 2016;63: 1042-1048. 